\title{
Perspective on abortion in Vietnamese Christian context
}

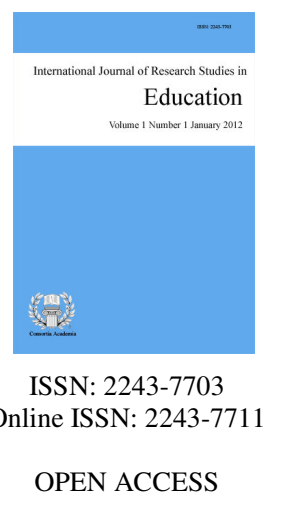

\section{Abstract}

Although abortion is decreasing in some countries, especially in the United States, it has always been a complicated, painful, and historically controversial issue in many countries throughout the world and throughout much of history. Much of the abortion debate is conducted between two opposing groups, one group holding a pro-life position and the other group holding a pro-choice position. There are arguments from both groups with explain defend their position. To date, abortion is not only a widespread, hotly debated issue, but above all, it is a mortal sin from the point of view of the Roman Catholic Church. However, because abortion is quite common and legal in many countries, including Vietnam, many people and Vietnamese Catholics today do not know whether abortion is a felony, so they have committed it. This essay aims to help Vietnamese Catholics understand that abortion is always, and that we must respect and protect pre-born children. This could be translated in the following way: All children born and pre-born must be welcome in life and protect in law.

Keywords: abortion, Roman Catholic Church, mortal sin, Vietnamese Catholics, immoral 


\section{Perspective on abortion in Vietnamese Christian context}

\section{Introduction}

Currently, Vietnam has one of the highest abortion rates in the world. As of 2016, Vietnam had the highest abortion rate in Asia, with around $40 \%$ of all abortions in Vietnam (VNExpress, 2016): There is an average of 2.5 abortions for every woman of reproductive age had 2.5 abortions. Youngsters from the ages of 13 to 19 accounted for $70 \%$ of all covert abortions in Vietnam, including some who some had more than one (Bui, 2016). It was reported that in May, 2021, police in the Ha Dong District of the city of Hanoi had discovered over 1,000 human fetuses in freezers inside an apartment (Phan, n.d.). All of this shows that abortion in Vietnam has reached a red alert level. The Roman Catholic Church affirms abortion as a mortal sin, condemns those who have abortions, and excommunicates those involved in a valid abortion (Code of Cannon Law, 1983, par.1398). This urgent matter calls for a thoughtful, systematic presentation of this topic. This paper, "Abortion is a Mortal Sin" will attempt to do this. In reality, numerous authors have investigated or written on this issue. However, this writer wishes to stress the gravity of abortion from the perspective of the Church, in the hope of helping people, particularly Vietnamese Catholics, understand that abortion is a murder and a crime. This essay will focus on four primary parts: 1) A brief overview of abortion; 2) The issue of abortion from the perspective of the Roman Catholic Church; 3) Various views; 4) My personal view.

\section{Review of literature}

The Catechism of the Catholic Church teaches that: "Mortal sin destroys charity in the heart of man by a grave violation of God's law; it turns man away from God, who is His ultimate end and His beatitude, by preferring an inferior good to Him" (Libreria Editrice Vaticana, 2003, par. 1855). Saint Thomas Aquinas explained how mortal sin destroys charity: "When the will sets itself upon something that is of its nature incompatible with the charity that orients man toward his ultimate end, then the sin is mortal by its very object ... whether it contradicts the love of God, such as blasphemy or perjury, or the love of neighbors, such as homicide or adultery...” (Libreria Editrice Vaticana, 2003b, par. 1856).

\section{Conditions for a sin to become a mortal sin:}

For a sin to be a mortal sin, three conditions must be met at the same time: grave matter, full knowledge and complete consent. Grave matter is specified by the Ten Commandments. Sins vary in severity: murder, for example, is significantly more serious than stealing, It's also important to consider who has been wronged: violence against parents is far more serious than violence against strangers. Mortal sin requires full knowledge and full consent of the will. It requires an understanding of the evil nature of the act, as well as its violation of God's rule. It also indicates permission that is intentional enough to constitute a personal decision. The voluntary nature is not diminished by feigned ignorance or hardness of heart but instead increased by it.

\section{A brief overview of abortion: What is abortion?}

In the medical sense, Wikipedia defines abortion as follows: "Abortion is the termination of a pregnancy by removal or expulsion of an embryo or fetus" (Wikipedia, n.d.). However, Karl H. Peschke gave another, more explicit definition of abortion: “Abortion is the removal of non-viable embryo or fetus from the mother's womb by human intervention, whether by killing the human being before removal from the womb, or whether by exposing the same to a certain death outside the womb" (Peschke, 2013, p. 334).

In 1995, Pope John Paul II also gave a direct definition of abortion in the Encyclical Evangelium Vitae: "procured abortion is the deliberate and direct killing, by whatever means it is carried out, of a human being in the initial phase of his or her existence, extending from conception to birth" (John Paul II, 1995, par. 58). 


\section{Reasons of abortion:}

Akinrinola Bankole, Susheela Singh, and Taylor Haas gave the following statistical results (Bankole et al., 1998): Worldwide, the most prevalent reason for women to have abortions is either to postpone or cease having children. The second most prevalent cause - socioeconomic issues - is the disruption of education or employment; father's lack of assistance; a desire to give children already born an education; and poverty, unemployment, or the inability to support additional children. Furthermore, issues with a husband or partner and a woman's feeling that she is too young are also significant causes. The qualities of women are linked to their abortion reasons: Older women and married women are likely to find limits with few exceptions. In Vietnam, women have abortions for the following principal reasons: limited awareness of contraceptives and low education. The rate of abortion for those with little education is relatively high, but people with elementary school graduation have the lowest rate of abortion (Nguyen, 2013).

\section{The Bible stresses life's sacredness:}

The Bible emphasizes human life right at conception and considers that life to be created by God: "You formed my inmost being; you knit me in my mother's womb. I praise you, because I am wonderfully made; wonderful are your works! My very self you know. My bones are not hidden from you, when I was being made in secret, fashioned in the depths of the earth. Your eyes saw me unformed; in your book all are written down; my days were shaped, before one came to be" (Ps 139: 13-16, NAB). Notably, in explaining his vocation, the prophet Jeremiah asserted that God had seen him, chosen him, and entrusted him with a prophetic mission even when he was nothing, even while he was not in his mother's womb: "Before I formed you in the womb I knew you, before you were born I dedicated you, a prophet to the nations I appointed you" (Jer 1:5, NAB). Thus, human life is sacred, and God has always loved man since he was a fetus in his mother's womb.

\section{The Bible condemns murder:}

Human life is inviolable, so the book of Genesis, the first book of the Bible, states that after Cain killed his brother Abel, God pointed Cain straight in the face and said: "What have you done? Your brother's blood cries out to me from the ground! Now you are banned from the ground hat opened its mouth to receive your brother's blood from your hand" (Gn 4: 10-14, NAB). God will demand an accounting blood of those who kill their kind: "Indeed for your own lifeblood I will demand an accounting: from every animal, I will demand it, and from a human being, each one for the blood of another, I will demand an accounting for human life. Anyone who sheds the blood of a human being, by a human being shall that one's blood be shed; for in the image of God have human beings been made." (Gn 9:5-6, NAB).

In the book of Exodus, God also defends the innocent and forbids killing the innocent and the righteous: "You shall keep away from anything dishonest. The innocent and the just you shall not put to death, for I will not acquit the guilty"(Ex 23:7, NAB). In the Sermon on the Mount, Jesus repeated this: "Do not kill" (Mt 5:21), adding to it the prohibition of anger, hatred, and vengeance. He even demanded that his disciples turn the other cheek to love their enemies. He did not defend Himself and told Peter to sheath his sword" (Libreria Editrice Vaticana, 2003c, par. 2258). If God especially respects and protects human life in such a way, then the fetus is certainly within God's sacred intention. Therefore, God will also "demand an accounting blood" of those who kill the fetus.

\subsection{The issue of abortion from the perspective of the Roman Catholic Church:}

\section{Abortion is murder:}

From the early Church, the Fathers of the Church condemned abortion, and abortion was considered murder. Athenagoras (flourished 2nd century AD) clearly demonstrated that Christians condemn women who use drugs for abortions to commit murder: "When we say that those women who use drugs to bring on abortion commit 
murder, and will have to give an account to God for the abortion, on what principle should we commit murder? For it does not belong to the same person to regard the very fetus in the womb as a created being, and therefore an object of God's care, and when it has passed into life, to kill it; and not to expose an infant, because those who expose them are chargeable with child-murder, and on the other hand, when it has been reared to destroy it. But we are in all things always alike and the same, submitting ourselves to reason, and not ruling over it." (Athenagoras, n.d.).

Tertullian (c.155 AD - c. $220 \mathrm{AD}$ ) called abortion murder because he believed that the fetus is a human being, a person: "The embryo, therefore, becomes a human being in the womb from the moment that its form is completed. The law of Moses, indeed, punishes with due penalties the man who shall cause abortion, inasmuch as there exists already the rudiment of a human being, which has imputed to it even now the condition of life and death, since it is already liable to the issues of both, although, by living still in the mother, it, for the most part, shares its own state with the mother" (Tertullian, n.d.).

Saint Basil of Caesarea (329-379) taught that the woman who has had an abortion committed not only murder but also suicide because she attacked herself: "The woman who purposely destroys her unborn child is guilty of murder. With us, there is no nice inquiry as to its being formed or unformed. In this case it is not only the being about to be born who is vindicated, but the woman in her attack upon herself; because in most cases women who make such attempts die. The destruction of the embryo is an additional crime, a second murder, at all events if we regard it as done with intent. The punishment, however, of these women should not be for life, but for the term of ten years. And let their treatment depend not on the mere lapse of time, but on the character of their repentance... Women also who administer drugs to cause abortion, as well as those who take poisons to destroy unborn children, are murderesses" (Basil of Caesarea, n.d.). In 692, the Council in Trullo taught: "Those who give drugs for procuring abortion, and those who receive poisons to kill the fetus, are subjected to the penalty of murder" (Trullo, n.d.).

\section{Abortion is a mortal sin:}

According to the conditions for a crime to become a felony above, it is clear that an abortion is a mortal sin when committed with full knowledge and complete consent (grave matter is always present). Because abortion is murder, those who have abortions know that the fetus is theirs and their own, and they must give their full permission for the abortion to occur.

In the Encyclical Casti Connubii, Pope Pius XI taught that abortion is a very serious sin: "Another very grave crime is to be noted, Venerable Brethren, which regards the taking of the life of the offspring hidden in the mother's womb. Some wish it to be allowed and left to the will of the father or the mother; others say it is unlawful unless there are weighty reasons which they call by the name of medical, social, or eugenic 'indication'. Because this matter falls under the penal laws of the state by which the destruction of the offspring begotten but unborn is forbidden, these people demand that the 'indication', which in one form or another they defend, be recognized as such by the public law and in no way penalized. There are those, moreover, who ask that the public authorities provide aid for these death-dealing operations, a thing, which, sad to say, everyone knows is of very frequent occurrence in some places" (Pius XI, 1930).

Following Pope Pius XI, Pope Pius XII also taught that it is illegal to destroy an innocent person's life in the womb or be born for any reason: "Every human being, even babies in the womb have the right to live 'directly' from God and not from parents, nor any human society or authority. Therefore, no human authority, no science, no 'designation'-whether medical, eugenics, social, economic, or ethical—can provide or suggest a list. reasonable legal meaning for the 'direct' intentional removal of innocent life, i.e., a removal intended to destroy, as an end in itself or as a means to that end, it's all illegal" (Pius XII, 1951).

In 1965, in the Pastoral Constitution on the Church in the Modern World, Gaudium et Spes, the Second Vatican Council showed that abortion is a terrible crime: "For God, the Lord of life has conferred on men the 
surpassing ministry of safeguarding life in a manner which is worthy of man. Therefore, from the moment of its conception life must be guarded with the greatest care while abortion and infanticide are unspeakable crimes" (Second Vatican Council, 1965).

In 1974, The Sacred Congregation for the Doctrine of the Faith has also affirmed that abortion is a mortal sin when stating that the law that permits abortion is immoral by its very nature: "It must, in any case, be clearly understood that whatever may be laid down by civil law in this matter, man can never obey a law which is in itself immoral, and such is the case of a law which would admit in principle the liceity of abortion" (Sacred Congregation for the Doctrine and Faith, 1974, par. 7).

In 1992, The Catechism of the Catholic Church clearly and unequivocally stated that abortion is a mortal sin: "Human life must be respected and protected absolutely from the moment of conception. From the first moment of his existence, a human being must be recognized as having the rights of a person - among which is the inviolable right of every innocent being to life" (Libreria Editrice Vaticana, 2003d, par. 2270).

"Since the first century, the Church has affirmed the moral evil of every procured abortion. This teaching has not changed and remains unchangeable. Direct abortion, that is to say, abortion willed either as an end or a means, is gravely contrary to the moral law: "You shall not kill the embryo by abortion and shall not cause the newborn to perish. God, the Lord of life, has entrusted to men the noble mission of safeguarding life, and men must carry it out in a manner worthy of themselves. Life must be protected with the utmost care from the moment of conception: abortion and infanticide are abominable crimes" (Libreria Editrice Vaticana, 2003e, par. 2271).

In 2004, the Church also teaches that abortion is a social sin because it is against the right of the fetus to live while it is still in the womb: "Certain sins, moreover, constitute by their very object a direct assault on one's neighbor. Such sins in particular are known as social sins. Social sin is every sin committed against justice due in relations between individuals, between the individual and the community, and also between the community and the individual. Social too is every sin against the rights of the human person, starting with the right to life, including that of life in the womb, and every sin against the physical integrity of the individual; every sin against the freedom of others, especially against the supreme freedom to believe in God and worship him; and every sin against the dignity and honor of one's neighbor. Every sin against the common good and its demands, in the whole broad area of rights and duties of citizens, is also social sin. In the end, social sin is that sin that "refers to the relationships between the various human communities. These relationships are not always in accordance with the plan of God, who intends that there be justice in the world and freedom and peace between individuals, groups, and peoples" (Pontificial Council for Justice and Peace, 2004, par. 118).

\subsection{Various Views}

\section{Abortion is wrong:}

Although it is not clear whether abortion is a sin or a mortal sin, in "Why Abortion is Immoral, Don Marquis (Marquis, 1989), professor of philosophy at Kansas University, argued that with rare exceptions, abortion is wrong for the same reason that killing an adult is wrong. He also stated that his argument rested neither on religious claims nor on Papal dogma. This argument is not subject to the objections of "speciesism" but refers to our intuition about young children.

\section{Dr. John Messerly (2015) summarized Marquis's “Why is abortion wrong” as follows:}

Marquis first noted that few philosophers consider that abortion is seriously wrong. And he also said that there is hardly any current support for the pro-life viewpoint. He assumed but did not try to prove "that whether or not abortion is morally permissible stands or falls on whether or not a fetus is a being whose life it is seriously wrong to end. Marquis raised a question: "Why is killing an adult wrong?" And he stated that killing is wrong 
because of its impact on the victim, mainly because it destroys a person's future.

Abortion is wrong prima facie (at first look) because it eliminates an adult's future, which does not rely on the fetus as a person. Marquis used an analogy with an argument against animal cruelty to further illustrate the structure of his argument. In both situations, the wrongness is justified by appealing to a natural property—pain and suffering or denial of a future-rather than personhood. All this did not indicate that abortion is always wrong, simply that it generally is.

In conclusion, killing a fetus is wrong because it has a future, which is what makes killing wrong. This addresses the traditional abortion problem of determining some feature that makes a fetus more like a person than a bunch of cells-brain waves, viability, and so on. That property represents its potential future. Marquis' argument is interesting. But from the very beginning, he said the following: "abortion is, except possibly in rare cases, seriously immoral". These "rare cases" include abortion after rape, abortion during the first fourteen days after conception when there is an argument that the fetus is not definitely an individual, abortion when the continuation of pregnancy endangers a woman's life, and when the fetus is anencephalic (Marquis, n.d.). According to this argument, abortions should be allowed in these rare cases. Unfortunately, this is contrary to the position of the Catholic Church because it concerns direct abortion, therapeutic abortion, eugenics or elective abortion, and "ethical" abortion.

Pope Paul VI, through the Congregation for the Doctrine of the Faith, reaffirmed the Church's teaching on the prevention of direct abortion as follows: "In reality, respect for human life is called for from the time that the process of generation begins. From the time that the ovum is fertilized, a life is begun which is neither that of the father nor of the mother, it is rather the life of a new human being with his own growth. It would never be made human if it were not human already" (Sacred Congregation for the Doctrine and Faith, 1974, par. 12).

On the issue of therapeutic abortion, Pope Pius XI has outspokenly rejected it as follow: "As to the 'medical and therapeutic indication' to which, using their own words, we have made reference, Venerable Brethren, however much we may pity the mother whose health and even life is gravely imperiled in the performance of the duty allotted to her by nature, nevertheless what could ever be a sufficient reason for excusing in any way the direct murder of the innocent? This is precisely what we are dealing with here. Whether inflicted upon the mother or upon the child, it is against the precept of God and the law of nature: 'Thou shalt not kill': The life of each is equally sacred, and no one has the power, not even the public authority, to destroy it. It is of no use to appeal to the right of taking away life for here it is a question of the innocent, whereas that right has regard only to the guilty; nor is there here question of defense by bloodshed against an unjust aggressor (for who would call an innocent child an unjust aggressor?); again there is not question here of what is called the 'law of extreme necessity' which could even extend to the direct killing of the innocent.

Upright and skillful doctors strive most praiseworthily to guard and preserve the lives of both mother and child; on the contrary, those show themselves most unworthy of the noble medical profession who encompass the death of one or the other, through a pretense at practicing medicine or through motives of misguided pity" (Pius XI, 1930, par. 63). The Congregation for the Doctrine of the Faith had more specific instructions on this matter. "Divine law and natural reason, therefore, exclude all right to the direct killing of an innocent man. However, if the reasons given to justify an abortion were always manifestly evil and valueless the problem would not be so dramatic.

The gravity of the problem comes from the fact that in certain cases, perhaps in quite a considerable number of cases, by denying abortion one endangers important values to which it is normal to attach great value, and which may sometimes even seem to have priority. We do not deny these very great difficulties. It may be a serious question of health, sometimes of life or death, for the mother; it may be the burden represented by an additional child, especially if there are good reasons to fear that the child will be abnormal or retarded; it may be the importance attributed in different classes of society to considerations of honor or dishonor, of loss of social standing, and so forth. We proclaim only that none of these reasons can ever objectively confer the right to 
dispose of another's life, even when that life is only beginning. With regard to the future unhappiness of the child, no one, not even the father or mother, can act as its substitute- even if it is still in the embryonic stage- to choose in the child's name, life or death. The child itself, when grown up, will never have the right to choose suicide; no more may his parents choose death for the child while it is not of an age to decide for itself. Life is too fundamental a value to be weighed against even very serious disadvantages" (Sacred Congregation for the Doctrine of the Faith, 1974, par. 14).

Regarding the issue of eugenics or elective abortion, Pope Pius XII emphatically stated: "Every human being, even babies in the womb have the right to live 'directly' from God and not from parents, nor any human society or authority. Therefore, no human authority, no science, no 'designation'-whether medical, eugenics, social, economic, or ethical—can provide or suggest a list. reasonable legal meaning for the 'direct' intentional removal of innocent life, i.e., a removal intended to destroy, as an end in itself or as a means to that end, it's all illegal" (Pius XII, 1951). In the Dignitas Personae, the Congregation of the Doctrine of the Faith also stated that eugenics or elective abortions are not allowed: "accepts selective abortion in order to prevent the birth of children affected by various types of anomalies. Such an attitude is shameful and utterly reprehensible since it presumes to measure the value of a human life only within the parameters of 'normality' and physical well-being, thus opening the way to legitimizing infanticide and euthanasia as well" (Sacred Congregation for the Doctrine of the Faith, 2008, par. 22).

Abortion is as ethical as pregnancy due to rape. On this matter, Pope Pius XII also stated clearly: "Every human being, even babies in the womb have the right to live 'directly' from God and not from parents, nor any human society or authority. Therefore, no human authority, no science, no 'designation'—whether medical, eugenics, social, economic, or ethical — can provide or suggest a list. reasonable legal meaning for the 'direct' intentional removal of innocent life, i.e., a removal intended to destroy, as an end in itself or as a means to that end, it's all illegal" (Pius XII, 1951). Although the baby was conceived when its mother was raped, it was completely innocent and needed a womb to be developed and born. More than anyone else, it needs to live in its mother's womb. If it is not possible to feed and raise that child, its mother can put it up for adoption by someone else.

\subsection{Personal View}

From my perspective, abortion is a mortal sin because it is an offense against God, others and oneself.

\section{Abortion is an offense against God:}

Abortion-killing life is not just about one person, and it also involves God. Indeed, God gave man ten commandments, of which the fifth commandment is: "You shall not kill" (Ex 20:13). "You have heard that it was said to the men of old, 'You shall not kill: and whoever kills shall be accountable to judgment.' But I say to you that everyone who is angry with his brother shall be accountable to judgment (Mt 5:21-22)" (Libreria Editrice Vaticana, 2003g, par. 2262).

The Catechism of the Catholic Church teaches that: "Human life is sacred because from its beginning it involves the creative action of God and it remains forever in a special relationship with the Creator, who is its sole end. God alone is the Lord of life from its beginning until its end: no one can under any circumstance claim for himself the right directly to destroy an innocent human being..." (Libreria Editrice Vaticana, 2003h, par. 2258). Therefore, abortion-killing is an offense against God, The Creator.

Every human being is the image of God, or more powerfully, each person has God in them. Moreover, Jesus once identified Himself with others, especially with the least people: "Amen, I say to you, whatever you did for one of these least brothers of mine, you did for me." (Mt 25:40, NAB). The fetus is a human being, a child of God, and identified by Jesus with Himself. Thus, Abortion kills not only a human being but also the Son, Jesus Christ. This shows how terrible abortion is and that abortion is indeed a serious crime. 
It is God who wants man to live, so He tries to protect people. Indeed, after Abel's first death caused by Cain, anyone could have killed Cain, but God said: "If anyone kills Cain, he will get revenge seven times over." (see. Gn 4:15, NAB). With God, there is no such thing as restoring justice by private means. Thus, whether abortion is due to a forced pregnancy or incest, it is against God's will and is a claim for justice as an individual.

Man is the only creature created by God for himself. The man appeared in response to the creative will of God. Therefore, right from when each person was not yet formed, did not exist, God called each person to come into the world. Moreover, man is called to reach the fullness of life that is to enter into the life of God.

There is one crucial thing that everyone needs to remember: God is the Creator and Lord of life and death. I alone, am God, and there is no god besides me. God said: "I alone, am God, and there is no god besides me. I who bring both death and life" (Deut 32:39, NAB). Hence, abortion is taking God's right over the lives of others. Stealing is a mortal sin (see. Libreria Editrice Vaticana, 2003i, par. 2401), then stealing God's ownership is indeed a mortal sin.

\section{Abortion is an offense against others:}

Life is so attached to humans that it is unforgivable if someone trespasses on it. In the Instruction Donum Vitae, the Church clearly stated: "Every human being's right to life and physical integrity from the moment of conception until death" (Sacred Congregation for the Doctrine of the Faith, 1987, par. III). Abortion affects the freedom and security of the body and affects the right of the fetus to live. Moreover, abortion is not only a violation of the right to life but also destroys the life of the fetus. Those who perform a valid abortion violate human rights because they do not consider the fetus a child, a person, or another person... but only see the fetus as something to "disturb" them. So, they need to be "discard" the fetus to protect their private life. Abortion is the denial that "someone" is human, an insult to the fetus as soon as it exists but has not yet appeared. This is the most severe insult in human relations and, in a way, abortion is similar to racism (Smedley, 2021) when these people do not recognize others as fellow human beings, so they do not accept others and discriminate against others, excluding them, even destroy them.

Jesus once said: "No one has greater love than this, to lay down one's life for one's friends" (Jn 15:13, NAB). Then why would a mother not sacrifice her life for the child in her womb but force the child to sacrifice its life for the mother? Thus, abortion is a deprivation, a self-made change of conscience and an answer for the child in the womb. In abortion, the mother destroys the life of the other person. That other person is the child in the womb, and it is an innocent, weak, defenseless human being, sometimes even a disabled and sick person.

\section{Abortion is an offense against oneself:}

The Creator God has provided for man to have a life so that that man can brighten the image of God in himself. By having an abortion, man has destroyed the image of God because God is the Creator, not the destroyer. When people have abortions, they reject the duty of parenthood that God has entrusted to them. At the same time, they also neglect their creative responsibility with God.

In the Gospel of Matthew, Jesus said: "You shall not kill; you shall not commit adultery; you shall not steal; you shall not bear false witness; honor your father and your mother; and you shall love your neighbor as yourself" (Mt 19:18-19, NAB), and "everyone who listens to these words of mine and acts on them will be like a wise man who built his house on the rock" (Mt 7:24, NAB). Therefore, abortion is clear proof that man disobeys God and makes himself unable to attain eternal life.

Elsewhere in the Gospel of Matthew, Jesus also taught: "Do to others whatever you would have them do to you" (Mt 7:12, NAB). Abortion is murder, is not wanting the baby in the womb to live. So, according to the words of Jesus, the person who performs the abortion also wants to be killed and does not want to live. This is somewhat similar to suicide, a mortal sin. 


\section{Conclusion}

Life is a mystery, and God creates human life. Yet, many people today dare to disregard and destroy human life right from the womb through abortion, especially Vietnamese. Vietnam has one of the highest abortion rates globally, with about two to three million abortions a year. The sad thing is that young Catholics in Vietnam today do not know whether abortion is a felony, so they have committed it. The Catholic Church has always maintained that abortion is a mortal sin and a murder. The Church's teachings constantly proclaim it and always defend the right to life of man, upholding the noble status of every human being brought into the world by the grace of God. If everyone, especially young Vietnamese Catholics today, always come to the Church and learns what the Church teaches, they will surely realize that abortion is a mortal sin and not sin anymore. Thus, the evil of abortion will gradually decrease and no longer exist. Human life is always protected from the time they are in the mother's womb, people will respect each other more and more appropriately, and the world will develop more and more.

\section{References}

Athenagoras. (n.d.). A Plea for the Christians 35. In Ante-Nicene Fathers, Volume II. Retrieved Sept 19, 2021, from https://www.newadvent.org/fathers/0205.htm

Bankole, A., Singh, S., \& Haas, T. (1998). Reasons why women have induced abortions: Evidence from 27 Countries. International Family Planning Perspectives, 24(3). https://doi.org/10.2307/3038208

Basil of Ceasarea (n.d.). Letter 188, II, VIII. Retrieved Sept 19, 2021, from https://www.newadvent.org/fathers/3202188.htm

Buchholz, K. (2020). U.S. Abortion Rate. Retrieved Sep 15, 2021, from https://www.statista.com/chart/19490/us-abortion-rate-guttmacher-institute/

Bui, H. N. (2016). Teenagers account for 70 percent of secret aboritons in Vietnam. VN Express. Retrieved Sep 15, 2021, from https://e.vnexpress.net/news/news/teenagers-account-for-70-percent-of-secret-abortions-in-vietnam-342 $\underline{8414 . h t m l}$

Code of Canon Law (1983). Par. 1398. Retrieved Sep 15, 2021, from https://www.vatican.va/archive/cod-iuris-canonici/eng/documents/cic_lib6-cann1364-1399_en.html\#TI TLE_VI

Code of Canon Law (1983b). Par. 1329. Retrieved Sep 25, 2021, from https://www.vatican.va/archive/cod-iuris-canonici/eng/documents/cic_lib6-cann1311-1363_en.html\#TI TLE_III

Encyclopedia. (n.d.). Pro-Choice-Pro-Life. In Social sciences. Retrieved Sep 15, 2021, from https://www.encyclopedia.com/social-sciences/applied-and-social-sciences-magazines/pro-choicepro-lif $\underline{\mathrm{e}}$

Gouveia, William, J. (2009). Contract and Covenant in American Politics: Religion in the Abortion \& Abolition Debates. Human Life Review, 35(4), 29-40. Retrieved Sept 28, 2021, from https://www-proquest-com.dlsu.idm.oclc.org/docview/211725343?accountid=190474\&pq-origsite=pri $\underline{\text { mo }}$

John Paul II. (1995). Evangelium Vitae. Retrieved Sept 17, 2021, from https://www.vatican.va/content/john-paul-ii/en/encyclicals/documents/hf_jp ii_enc_25031995_evangelium-vitae.html

Libreria Editrice Vaticana (2003). Catechism of the Catholic Church, par. 1855. Retrieved Sep 15, 2021, from https://www.vatican.va/archive/ENG0015/_P6C.HTM

Libreria Editrice Vaticana (2003b). Catechism of the Catholic Church, par. 1856. Retrieved Sept 17, 2021, from https://www.vatican.va/archive/ENG0015/_P6C.HTM

Libreria Editrice Vaticana (2003c). Catechism of the Catholic Church, par. 2258. Retrieved Sept 18, 2021, from https://www.vatican.va/archive/ENG0015/_P7Y.HTM 
Ngo, H. T.

Libreria Editrice Vaticana (2003d). Catechism of the Catholic Church, par. 2270. Retrieved Sept 24, 2021, from https://www.vatican.va/archive/ENG0015/_P7Z.HTM

Libreria Editrice Vaticana (2003e). Catechism of the Catholic Church, par. 2271. Retrieved Sept 24, 2021, from https://www.vatican.va/archive/ENG0015/_P7Z.HTM

Libreria Editrice Vaticana (2003f). Catechism of the Catholic Church, par. 1463. Retrieved Sept 25, 2021, from https://www.vatican.va/archive/ENG0015/_P4E.HTM

Libreria Editrice Vaticana (2003g). Catechism of the Catholic Church, par. 2262. Retrieved Sept 28, 2021, from https://www.vatican.va/archive/ENG0015/_P7Z.HTM

Libreria Editrice Vaticana (2003h). Catechism of the Catholic Church, par. 2258. Retrieved Sept 28, 2021, from https://www.vatican.va/archive/ENG0015/_P7Y.HTM

Marquis, D. (n.d.). An argument that abortion is wrong. In Journal of Philosophy. Retrieved Sep 15, 2021, https://homeweb.csulb.edu/ cwallis/382/readings/160/marquis.html

Marquis, D. (1989). Why abortion is immoral. The Journal of Philosophy, 86(4), 183-202. Retrieved Sep 26, 2021, from https://www.jstor.org/stable/2026961

Martín, I. S. (2016). Pope Francis calls abortion. Retrieved Sept 28, 2021, from https://cruxnow.com/vatican/2016/11/pope-francis-calls-abortion-horrendous-crime-grave-sin/

Messerly, J. G. (2015). Summary and Critique of the Thermodynamic Helgeson. Pdf. Retrieved Sep 26, 2021, from https://reasonandmeaning.com/2015/05/24/summary-of-why-abortion-is-immoral-donald-marquis/

Nguyen, D. D. (2013). Abortion in America and Vietnam. Retrieved Sept 17, 2021, from https://www.slideshare.net/didicham/abortion-in-america-and-vietnam

Peschke, K. H. (2013, p.334). Christian Ethics ( $3^{\mathrm{r}}$ ed.). Bangalore, India: Theological Publications in India.

Phan, A. (n.d.). 1,000 human fetuses discovered frozen in Hanoi apartment. 2021. Retrieved Sept 15, 2021, from https://e.vnexpress.net/news/news/1-000-human-fetuses-discovered-frozen-in-hanoi-apartment-428596 $\underline{8 . h t m l}$

Pius XI. (1930). Casti connubii. Retrieved Sep 15, 2021, from https://www.vatican.va/content/pius-xi/en/encyclicals/documents/hf_p-xi_enc_19301231_casti-connubi i.html

Pius XII. (1951). Address to participants in the conference on Catholic-Lutheran Relations. Retrieved Sep 20, 2021, from https://www.vatican.va/content/pius-xii/it/speeches/1951/documents/hf_p-xii_spe_19511029_ostetriche $\underline{. h t m l}$

Pontifical Council for Justice and Peace. (2004). Compendium of the social doctrine of the Church. Retrieved Sept 20, 2021, from https://www.vatican.va/roman_curia/pontifical_councils/justpeace/documents/rc_pc_justpeace_doc_20 060526_compendio-dott-soc_en.html\#

Sacred Congregation for the Doctrine of the Faith (1974). Declaration on procured abortion. Retrieved Sept 20, 2021, from https://www.vatican.va/roman_curia/congregations/cfaith/documents/rc_con_cfaith_doc_197411_declar ation-abortion_en.html

Sacred Congregation for the Doctrine of the Faith (2008). Instruction Dignitas Personae. Retrieved from https://www.vatican.va/roman_curia/congregations/cfaith/documents/rc_con_cfaith_doc_20081208_dig nitas-personae_en.html

Sacred Congregation for the Doctrine of the Faith (1987). Instruction on respect for human life in its origin and on the dignity of procreation replies to certain questions of the day, par. III. Retrieved Sept 28, 2021, from https://www.vatican.va/roman_curia/congregations/cfaith/documents/rc_con_cfaith_doc_19870222_res pect-for-human-life_en.html

Second Vatican Council. (1965). Gaudium et Spes. Retrieved Sept 20, 2021, from https://www.vatican.va/archive/hist_councils/ii_vatican_council/documents/vatii_const_19651207_gau dium-et-spes_en.html

See. Libreria Editrice Vaticana (2003i). Catechism of the Catholic Church, par. 2401. Retrieved Sept 28, 2021,

54 Consortia Academia Publishing (A partner of Network of Professional Researchers and Educators) 
from https://www.vatican.va/archive/ENG0015/_P89.HTM

Smedley, A. (2021). Racism. Retrieved Sep 15, 2021, from https://www.britannica.com/topic/racism

Tertullian. (n.d.). A Treatise on the souls 37. Retrieved Sept 19, 2021, from

https://www.newadvent.org/fathers/0310.htm

Trullo Council. (n.d.). Canon 91. Retrieved Sept 19, 2021, from https://www.newadvent.org/fathers/3814.htm

VNExpress. (2016). Abortion rate in Vietnam highest in Asia. VN Express International. Retrieved Sept 15, 2021, from https://e.vnexpress.net/news/news/abortion-rate-in-vietnam-highest-in-asia-3476746.html

Wikipedia. (n.d.). Abortion. Retrieved Sept 17, 2021, from https://en.wikipedia.org/wiki/Abortion 
Ngo, H. T.

56 Consortia Academia Publishing (A partner of Network of Professional Researchers and Educators) 